\title{
Early Growth Characteristics of Seven Grafted Varieties and Non- Grafted Seedling Pawpaw
}

\author{
Anthony Bratsch, ${ }^{1}$ Robert Bellm, ${ }^{2}$ and Don Kniepkamp ${ }^{3}$
}

AdDitional INDEX wORDs. Asimina triloba, rootstock, anthesis, native, scaffold, axillary

\begin{abstract}
SUMmARY. Following spring planting in 1998, and for four seasons (1998-2001), early growth and development were characterized for seven grafted [PawPaw Foundation (PPF), Frankfort, Ky.) pawpaw Regional variety trial (PRVT) rootstock] pawpaw (Asimina triloba) varieties, 'Davis', 'Taylor', 'Rebecca's Gold', 'Sunflower', 'Overleese', 'Prolific', 'Wells', and one nongrafted seedling strain. Survival rate after four seasons was $96.5 \%$ for grafted trees and $100 \%$ for seedling trees. Entries exhibited significant differences in total height, trunk cross-sectional area (TCSA), average shoot length, first winter cold injury and percent bloom. By the end of 2000, seedling tree height and TCSA were greater as compared to the named varieties. Seedling height averaged $134 \mathrm{~cm}(52.8$ inches $)$, with a TCSA of $4.54 \mathrm{~cm}^{2}(0.704$ inch $)$, while the least vigorous variety (Davis) had an average height of $77 \mathrm{~cm}(30.3$ inches) and a TCSA of $1.54 \mathrm{~cm}^{2}\left(0.239\right.$ inch $\left.^{2}\right)$. Average shoot length was significant only in the year of planting, ranging from $39.3 \mathrm{~cm}$ (15.47 inches) for 'Davis', to $61.3 \mathrm{~cm}(24.13$ inches) for 'Sunflower'. Tip dieback occurred in the winter following planting on all varieties; this damage ranged from $23.3 \%$ ('Taylor') to $73.4 \%$ ('Overleese'). In 1999, lower axillary shoots (LSL) breaking below the damaged tips grew longer [31.1 to $50.6 \mathrm{~cm}$ (12.24 to 19.92 inches)] than upper distal axillary shoots (DASL) [15.8 to $44.6 \mathrm{~cm}$ (6.22 to 17.56 inches)], indicating a lack of apical dominance and vigor of emerging top buds. All named varieties developed flower buds by the spring of the fourth season, with budding ranging from an average of 0.5 buds/tree ('Rebeccas Gold') to 6.0 buds/tree ('Prolific'). Viability of these buds as determined by successful anthesis ranged from $0.4 \%$ ('Davis') to $63.8 \%$ ('Wells'). No fruit were set from these flowers.
\end{abstract}

P

awpaw is the only temperate member of the tropical custard-apple family (Annonacea) (Bailey, 1960) and is the largest native fruit in North America (Darrow, 1975). It is endemic to the eastern U.S. and it grows in the wild as far north as Ontario, Canada, south to Florida, and west to Nebraska (Kral, 1960). It has received attention in recent years as a potential new crop with multiple uses, including fresh-market sales of the custard-like fruit, and the vegetative parts have medicinal and insecticidal properties (Layne, 1996). A PRVT was established at 12 locations across the United States, coordinated by staff at Kentucky State University, (KSU) Frankfort, Ky. (Pomper et al., 1999).

\footnotetext{
University of Illinois Extension, Edwardsville Extension Center, 200 University Park Dr., Edwardsville, IL 62025.

This project was developed to evaluate the potential of several alternative horticultural crops for southern Illinois growers. "Native Fruits and Nuts With Commercial Potential", was initiated in 1997 and funded as a subgrant within the larger framework of a sustainable agriculture systems grant through the USDA Conservation 2000 program, written by the Illinois Department of Agriculture (IDOA SCCS and WC SA97-57). The horticulture portion of the project included evaluation of several species, and focused primarily on pecan (Carya illinoensis), black walnut (Juglans nigra) and pawpaw (Asimina triloba) variety evaluations. The authors would like to acknowledge and thank the staff of the Illinois Department of Agriculture, the St. Clair County Soil and Water Conservation District and others associated with the Henry White Farm Project. In addition we would like to express our appreciation to the members of the Illinois Nut Tree Growers Association and volunteers from the University of Illinois Master Gardener program, Madison/St. Clair County Extension Unit, as well as other interested enthusiasts who have been instrumental in their assistance in the maintenance and care of these experimental plots.

${ }^{1}$ Assistant professor. Current address: Department of Horticulture, 301 Saunders Hall, Virginia Tech, Blacksburg, VA 24061 .

${ }^{2}$ Extension educator, crop systems.

${ }^{3}$ Master gardener, University of Illinois Extension, Madison/St. Clair Unit, \#l South Third Street Belleville, IL
} 62222 . 
Although Illinois was not part of the multilocation effort, our goal was to contribute to this study using the limited number of grafted varieties available on the market in 1998.

Information is limited on the early developmental aspects of known varieties in a field setting. Seedlings are sensitive to ultraviolet light (Peterson, 1991), yet pawpaws grow and set fruit best in full sunlight (Willson and Schemske, 1980). Cultural studies have focused primarily on propagation, including seedling production and grafting techniques (Callaway, 1992, 1993; Layne, 1996; Pomper et al., 2002a, 2002b, 2002 c). In recent years, PPF distributed seed for rootstock purposes to commercial nurseries that was harvested from open-pollinated half-sib trees in rows 6 and 7 at the PPF orchard located at the Western Maryland Research and Education Center, Keedysville, Md. The same seedling-source rootstock was also used in the 12 PRVT plantings (Pomper etal., 1999). The primary goal of this study was to compare the early vegetative and reproductive characteristics of varieties grafted onto seedling rootstock with similar genetic background, and to demonstrate the potential of pawpaw as an alternative and sustainable fruit crop for small-scale orchards for southwestern Illinois.

\section{Materials and methods}

Site preparation for this study began in Spring 1997, and data were recorded through Spring 2001. The site was located near Belleville, Ill., in USDA Hardiness Zone 6A (lat. $38^{\circ} 28^{\prime} \mathrm{N}$, long. $90^{\circ} 2^{\prime} \mathrm{W}$ ) and the soil was a $113 \mathrm{~A}$ Oconee silt loam, (fine, montmorillonitic, mesic Udollic Ochraqualfs). Soil nutrient and physical parameters were measured 15 Apr. 1997. Soil test results were $\mathrm{pH}$ - 5.9; phosphorus $30.3 \mathrm{~kg} \cdot \mathrm{ha}^{-1}$ ( $27 \mathrm{lb} /$ acre); potassium $214.1 \mathrm{~kg} \cdot \mathrm{ha}^{-1}(191 \mathrm{lb} /$ acre $)$; organic matter $2.2 \%$; cation exchange capacity 16.6 meq; all micronutrients in standard ranges. Particle size analysis indicated soil texture was $17.5 \%$ sand, $77.5 \%$ silt, and $5 \%$ clay. On 30 Apr. 1997 , $280.2 \mathrm{~kg} \cdot \mathrm{ha}^{-1}(250 \mathrm{lb} /$ acre $)$ 18-46-0 $(18 \mathrm{~N}-20.1 \mathrm{P}-0 \mathrm{~K})$ and $224.2 \mathrm{~kg} \cdot \mathrm{ha}^{-1}$ (200 lb/acre) $0-0-60(0 \mathrm{~N}-0 \mathrm{P}-49.8 \mathrm{~K})$ were broadcast. The site was then chisel plowed in two directions and disced twice. Ladino clover (Trifolium repens) was sown at $4.5 \mathrm{~kg} \cdot \mathrm{ha}^{-1}$ (4 lb/acre), rolled, and allowed to grow through 1997. Final preparation for planting began in early May 1998. To ensure adequate soil drainage, raised beds were formed by alternate-direction moldboard plowing, which incorporated the ladino cover crop into the soil. Ridges were smoothed by discing, resulting in finished beds 20.3 to $30.5 \mathrm{~cm} \times 1.5 \mathrm{~m}$ wide ( 8 to 12 inches $\times 5 \mathrm{ft}$ ) on $7.6-\mathrm{m}$ $(25-\mathrm{ft})$ centers.

Seven named pawpaw varieties ('Davis', 'Taylor', 'Rebeccas Gold', 'Sunflower', 'Overleese', 'Prolific' and 'Wells' were commercially grafted (Northwoods Nursery, Mollala, Ore.) onto PRVT rootstock using whip-grafting at a height of 7.6 to $15.2 \mathrm{~cm} \mathrm{(3}$ to 6 inches). Non-grafted seedlings of the PRVT rootstock were also included for comparative purposes. Trees were grown in deep $5.7 \times 30.5-\mathrm{cm}\left(2^{1 / 4} \times\right.$ 12 inches) pots in a greenhouse. Trees were shipped in full leaf; trunk diameter ranged in size from 3.2-6.4 $\mathrm{mm}(1 / 8$ $1 / 4$ inch) and tree height was 30.5 to $61.0 \mathrm{~cm}$ (12 to 24 inches). Trees were field-planted 28 May 1998, with $2.1 \mathrm{~m}$ $(7 \mathrm{ft})$ between trees and $7.6 \mathrm{~m}$ between rows, in a randomized complete block design with eight replications for the grafted varieties and four replicates for the seedlings. At planting, a soil ridge basin was formed around each tree to hold water. Tree shelters [0.9-m-tall $(3-\mathrm{ft}) \times 15.2-\mathrm{cm}$-diameter fiberglass composite tubes; Tubex Treeshelters, Treeessentials Inc., Mendota Heights, Minn.] were placed around each tree after planting for the duration of the first season and through the 1998-99 winter. Pawpaws were described as an understory tree (Sargent, 1890). Although they grow and fruit well in full-sun culture, tree shelters were recommended for protection from direct sunlight the first season of growth (D. Layne, personal communication). Tree shelters also provide a windbreak and protection from browsing animals and herbicide applications. Trees were watered thoroughly by hand at planting and again on 15 July and 11 Sept. to supplement natural rainfall, which was generally adequate through 1 Aug. A transplant solution [Peters 20-20-20 (20N-8.7P-16.6K) Scotts Co., Marysville, Ohio] at $500 \mathrm{mg} \cdot \mathrm{L}^{-1}$ (ppm), $0.95 \mathrm{~L}$ (1 qt) per tree; $1.5 \mathrm{~g}$ $(0.05 \mathrm{oz}$.) nitrogen $(\mathrm{N})$ per tree)] was applied 12 June. Trees were fertilized again 13 May 1999 with soluble fertilizer [Peters 20-20-20 at $850 \mathrm{mg} \cdot \mathrm{L}^{-1}$, $0.95 \mathrm{~L}$ per tree; $2.5 \mathrm{~g}(0.09 \mathrm{oz}) \mathrm{N}$ per plant]. On 14 Apr. $2000,10 \mathrm{~g}(0.35 \mathrm{oz})$ $\mathrm{N}$ per tree as ammonium sulfate $(21 \%$
N) was surface broadcast in a $0.76 \mathrm{~m}$ $(2.5 \mathrm{ft})$ square around each tree.

Hardwood chip mulch was applied in a 1.2 -m-diameter $(4-\mathrm{ft})$ area, 10.2 $\mathrm{cm}$ (4 inches) deep around each tree on 15 July 1998. To help conserve soil moisture, on 10 Sept. mulch was applied between trees in a 0.9 - $\mathrm{m}$ band. Hardwood chips controlled weeds and conserved water in plantings at KSU (Layne, 1996). Hardwood chip mulch [5.1 to $7.6 \mathrm{~cm}$ (2 to 3 inches)] was applied twice in 1999 to cover the entire ridge surface. Soil within 15.2 to 20.3 $\mathrm{cm}$ of the tree trunks was not mulched to prevent rodent and fungal problems. No mulch was added in 2000.

A $2 \%$ glyphosate solution was spot sprayed around the trees and on mulched and unmulched row surface areas to control weeds twice in each year. Weeds close to trees were removed by hand. The tree shelters proved useful for protecting the trees from herbicide drift in the establishment year. In early spring 2000 , simazine at $4.7 \mathrm{~L} \cdot \mathrm{ha}^{-1}(2$ qt/acre) (experimental use only) was applied on the ridge to within 30.5 $\mathrm{cm}(\mathrm{l} \mathrm{ft})$ of the trunks for preemerge weed control.

To evaluate natural growth habit, trees were not pruned except for dead tissue removal. Tree height, number of shoots/tree, and average shoot length were recorded in 1998, 1999, and 2000. Early bud break number from the original grafted whip and resulting primary scaffold development (no. three tiers) were also noted. Length of the longest shoot (LSL) and the most distal axillary shoot (DASL) were recorded in 1999 as an indication of relative apical dominance following the loss of the terminal shoot to cold damage. Overwinter damage was quantified by the length of dieback in the first-year whip (FYWD) in Spring 1999 and third-year terminal dieback (TYTD) in Spring 2001. Damage was expressed as the length of dieback and the percentage of the shoot length with dieback. TCSA at $20.3 \mathrm{~cm}(10.2$ to $15.2 \mathrm{~cm}$ above the graft), maximum tree spread, and number and percentage of shoots longer than $30.4 \mathrm{~cm}$ were recorded for each tree in Spring 2001. The number of floral buds present were counted on 18 Apr., and at anthesis (no. of open blooms) on 27 Apr. and 9 May 2001.

All data were analyzed using analysis of variance with CoStat 6.1 (CoHort Software, Monterey, Calif.). With unequal sample sizes, a conser- 
Table 1. End of season tree height, spread, shoot length, vigor and trunk cross-sectional area (TCSA) for seven grafted pawpaw varieties and one nongrafted seedling strain planted in 1998 near Belleville, Ill.

\begin{tabular}{|c|c|c|c|c|c|c|c|c|c|}
\hline \multirow[b]{3}{*}{ Variety } & & & \multirow{2}{*}{\multicolumn{2}{|c|}{$\begin{array}{l}\text { Spread } \\
(\mathrm{cm})\end{array}$}} & \multirow{2}{*}{\multicolumn{2}{|c|}{$\begin{array}{l}\text { Avg shoot } \\
\text { length }(\mathrm{cm})\end{array}$}} & \multicolumn{3}{|c|}{$\begin{array}{c}\text { Vigor parameters, } 2000 \\
\text { Shoots }>30 \mathrm{~cm} \\
(11.8 \text { inches }) \text { long }\end{array}$} \\
\hline & \multicolumn{2}{|c|}{$\mathrm{Ht}(\mathrm{cm})$} & & & & & & & TCSA \\
\hline & $1998^{z}$ & 1999 & 2000 & 2000 & 1998 & 1999 & (no./tree) & $(\% /$ total $)$ & $\left(\mathrm{cm}^{2}\right)$ \\
\hline Davis & $47.5 b^{y}$ & 54.6 & $77.0 \mathrm{c}$ & 40.9 & $39.3 \mathrm{c}$ & 21.9 & 6.6 & 37.3 & $1.54 \mathrm{c}$ \\
\hline Taylor & $44.0 \mathrm{c}$ & 56.3 & $95.6 \mathrm{c}$ & 47.4 & $36.8 \mathrm{c}$ & 21.0 & 8.0 & 64.7 & $2.23 \mathrm{bc}$ \\
\hline Rebeccas Gold & $47.3 \mathrm{bc}$ & 55.8 & $108.5 \mathrm{ab}$ & 50.0 & $39.7 \mathrm{c}$ & 23.5 & 8.4 & 52.6 & $2.45 \mathrm{bc}$ \\
\hline Sunflower & $68.0 \mathrm{a}$ & 71.9 & $117.9 \mathrm{ab}$ & 54.0 & $61.3 \mathrm{a}$ & 29.6 & 11.3 & 49.6 & $2.78 \mathrm{c}$ \\
\hline Overleese & $52.3 \mathrm{abc}$ & 58.8 & $98.9 c$ & 50.3 & $46.3 \mathrm{bc}$ & 33.7 & 8.6 & 47.5 & $2.27 \mathrm{bc}$ \\
\hline Prolific & $66.4 \mathrm{a}$ & 72.9 & 129.9 & 53.0 & $59.4 \mathrm{ab}$ & 29.4 & 12.3 & 53.4 & $3.44 \mathrm{~b}$ \\
\hline Wells & $62.3 \mathrm{ab}$ & 66.7 & 114.8 & 46.0 & $55.8 \mathrm{ab}$ & 28.3 & 9.5 & 56.9 & $1.99 \mathrm{c}$ \\
\hline Seedling & $50.5 \mathrm{abc}$ & 76.5 & $134.0 \mathrm{a}$ & 57.8 & $50.5 \mathrm{abc}$ & 39.3 & 9.5 & 63.6 & 4.54 \\
\hline$P^{k}$ & 0.010 & 0.160 & 0.001 & 0.233 & 0.005 & 0.218 & 0.104 & 0.218 & 0.049 \\
\hline
\end{tabular}

${ }^{2}$ Values are means of eight trees/variety in 1998; in 1999 and 2000 'Sunflower' and 'Overleese', $\mathrm{N}=7$ trees. For seedling trees, $\mathrm{N}=4$.

${ }^{\mathrm{Y}}$ Means separated by least significant difference (LSD) values at $P=0.05$ significance level; $1.0 \mathrm{~cm}=0.39$ inches; $1.00 \mathrm{~cm}^{2}=0.155$ inches .

xSignificance of variety main effect after analysis of variance.

vative Least significant difference was used for mean separation. An arcsine transformation of percentage data was conducted prior to analysis of variance and back-transformed for presentation purposes (Little and Hills, 1978).

\section{Results and discussion}

Tree survival rate was $96.5 \%, 100 \%$, and $100 \%$ for 1998,1999 , and 2000 respectively, and did not vary by variety. Seedling survival rate was $100 \%$. Following the end of the first growing season, 1998, the pawpaw varieties Sunflower and Prolific were significantly taller than 'Taylor' but not the other varieties (Table 1). Tree height was not different between varieties in 1999. However by the end of 2000 'Prolific' and the seedling trees were significantly taller than 'Davis', 'Taylor', and 'Overleese'. Canopy spread measured at the end of the third season was not influenced by variety.

Average shoot length in 1998 fol- lowed a similar pattern as tree height due to minimal branching of the whip by seasons end (Table 1). Average shoot length in 1999 was considerably less than in 1998, primarily due to increased shoots per plant from whip bud breaks (WBB, Table 2 ) and less vigorous growth. Average shoot length was not influenced by variety in 1999. In 2000 both number and percentage of shoots $>30 \mathrm{~cm}$ ( 11.8 inches) long were not influenced by variety. In 2000 , the seedlings had larger trunks than 'Davis', 'Taylor', 'Rebeccas Gold', 'Overleese' and 'Wells' (TCSA, Table 1). Number of multiple (tertiary) branched scaffolds formed by the end of the third year (2000) did not differ significantly among varieties and generally reflected initial WBB number measured at the end of 1999 (Table 2).

Following the winter after planting (1998-99), tip dieback occurred on all trees. Subsequent growth as represented by WBB number and end-of-season (1999) shoot lengths were compared. There was no significant difference among varieties in WBB number or the average length of the shoot that broke at the top of the damaged whip (DASL) or in the length of the longest shoot on the whip (LSL) (Table 2). However, for each variety, average LSL was always greater than DASL, with these mid-stem and lower shoots often becoming the dominant scaffolds on the tree, out-growing the apically located shoots. DASL ranged from 15.8 to $44.6 \mathrm{~cm}$ (6.22 tol7.56 inches) while shoots originating lower on the whip grew longer [LSL 30.4 to $50.6 \mathrm{~cm}$ (11.97 to 19.92 inches)]. This habit of dominant, lower axillary shoot growth should be considered as early training and pruning regimes are developed for pawpaw. Based on observations from natural tip loss made in this study, as branch heading cuts are made,

Table 2. Whip bud break (WBB), longest shoot length (LSL), distal axillary shoot length (DASL) and branch number characteristics for seven grafted pawpaw varieties and one nongrafted seedling strain planted in 1998 near Belleville, Ill.

\begin{tabular}{|c|c|c|c|c|c|}
\hline \multirow[b]{2}{*}{ Variety } & \multirow{2}{*}{$\begin{array}{c}\text { WBB } \\
(\text { no. } / \text { tree })^{z}\end{array}$} & \multicolumn{2}{|c|}{$\begin{array}{c}1999 \\
\text { Shoot length }(\mathrm{cm})\end{array}$} & \multicolumn{2}{|c|}{$\begin{array}{c}2000 \\
\text { Branch/shoot no. }\end{array}$} \\
\hline & & LSL & DASL & (scaffolds/tree) & (shoot tips/tree) \\
\hline Davis & 4.8 & $31.1^{y}$ & 21.4 & 3.9 & 16.0 \\
\hline Taylor & 4.8 & 30.4 & 21.7 & 3.6 & 13.4 \\
\hline Rebeccas Gold & 4.0 & 36.7 & 15.8 & 3.8 & 16.4 \\
\hline Sunflower & 4.3 & 40.1 & 26.2 & 4.1 & 22.9 \\
\hline Overleese & 3.9 & 44.2 & 35.5 & 3.6 & 17.9 \\
\hline Prolific & 4.4 & 42.1 & 23.3 & 3.8 & 23.6 \\
\hline Wells & 4.3 & 38.8 & 26.1 & 4.0 & 18.0 \\
\hline Seedling & 3.8 & 50.6 & 44.6 & 3.8 & 15.3 \\
\hline$P^{\mathrm{x}}$ & 0.810 & 0.232 & 0.206 & 0.962 & 0.061 \\
\hline
\end{tabular}

'Values are means of eight trees/variety; for 'Sunflower' and 'Overleese' $\mathrm{N}=7$; for seedlings $\mathrm{N}=4$.

y $1.0 \mathrm{~cm}=0.39$ inches.

xSignificance of variety main effect after analysis of variance. 
Table 3. First-year whip dieback (FYWD), third-year terminal dieback (TYTD) from cold injury, and fourth-year year bloom characteristics for seven grafted pawpaw varieties and one nongrafted seedling strain planted in 1998.

\begin{tabular}{|c|c|c|c|c|c|c|}
\hline \multirow[b]{2}{*}{ Variety } & \multicolumn{2}{|c|}{1998 FYWD } & \multicolumn{2}{|c|}{2000 TYTD } & \multicolumn{2}{|c|}{2001 Bloom } \\
\hline & Loss $(\mathrm{cm})^{\mathrm{z}}$ & Loss (\%) & (no./tree) & $(\% \text { total })^{y}$ & Buds/tree (no.) & Viable (\%) \\
\hline Davis & $15.4 b c^{x}$ & $33.0 \mathrm{~b}$ & 1.9 & 12.9 & 2.5 & $0.4 \mathrm{c}$ \\
\hline Taylor & $10.0 \mathrm{c}$ & $20.9 \mathrm{~b}$ & 1.6 & 12.3 & 2.3 & $0.6 \mathrm{c}$ \\
\hline Rebeccas Gold & $9.0 \mathrm{c}$ & $27.5 \mathrm{~b}$ & 2.9 & 12.5 & 0.5 & $50.0 \mathrm{ab}$ \\
\hline Sunflower & $25.4 \mathrm{ab}$ & $42.1 \mathrm{~b}$ & 1.1 & 2.6 & 4.3 & $1.0 \mathrm{c}$ \\
\hline Overleese & $35.3 \mathrm{a}$ & $76.5 \mathrm{a}$ & 2.6 & 13.7 & 5.6 & $0.7 \mathrm{c}$ \\
\hline Prolific & 17.7 bc & $28.3 \mathrm{~b}$ & 2.6 & 10.6 & 6.0 & $4.1 \mathrm{bc}$ \\
\hline Wells & $24.1 \mathrm{abc}$ & $44.1 \mathrm{~b}$ & 3.6 & 16.2 & 3.6 & $63.8 \mathrm{a}$ \\
\hline Seedling & $18.6 \mathrm{abc}$ & $39.3 \mathrm{~b}$ & 4.8 & 32.0 & 0.0 & $0.0 \mathrm{c}$ \\
\hline$P^{\mathrm{N}}$ & 0.021 & 0.014 & 0.307 & 0.197 & 0.121 & 0.012 \\
\hline
\end{tabular}

${ }^{2}$ Values are means of eight trees/variety in 1998; in 1999, 2000, and 2001, for 'Sunflower' and 'Overleese' trees $\mathrm{N}=7$; for seedling trees $\mathrm{N}=4$.

Percent of total tips on tree.

Means separated by least significant difference (LSD) values at $P=0.05$ significance level; $1.0 \mathrm{~cm}=0.39$ inches

"Significance of variety main effect after analysis of variance.

buds will likely break evenly along the stem, but those furthest from the cut will be the most vigorous. At the end of 2000, average shoot lengths were not recorded, but total shoot numbers ranged from 13.4 ('Taylor'), to 23.6 ('Prolific') (Table 2).

Loss of first season whip growth (FYWD) to cold damage the winter after planting ranged from 20.9 to $76.5 \%$ (Table 3). Temperature data during the coldest months (Dec. 1998-Feb. 1999 ) indicate a period mean minimum temperature of $-1.7^{\circ} \mathrm{C}\left(28.94^{\circ} \mathrm{F}\right)$ and a period minimum of $-16.4{ }^{\circ} \mathrm{C}(2.48$ ${ }^{\circ} \mathrm{F}$ ) (Midwest Climate Information System, Belleville SIU Research Center, Belleville, Ill.). Pawpaw is known to be a hardy species, so winter injury was unexpected. The variety 'Overleese' lost significantly more top growth than 'Taylor' and 'Rebeccas Gold'. When evaluated as a percent of total growth 'Overleese' lost more top growth than all other entries. Both 'Sunflower' and 'Wells' lost a higher percentage than 'Taylor' which had the least percent loss among the named varieties. One tree of 'Overleese' and 'Sunflower' died following the winter of 1998-99, probably due to cold damage. During Winter 1999-2000, no damage was noted in any variety. However, following the third winter (2000-01), dieback of tips (TYTD) was noted but was not influenced by variety (Table 3 ). For the last two winters, the period minimum temperature from December to February was $-15.8^{\circ} \mathrm{C}\left(3.56^{\circ} \mathrm{F}\right)$ and -16.4 ${ }^{\circ} \mathrm{C}$, respectively. These data indicate that relative hardiness and/or fall acclimation differences may be present in the varieties tested. Because grow tubes were left on during the first winter, it is suspected that the shoot loss was related to acclimation and hardening characteristics, as trees grew later into the fall with tube protection. Fluctuations in fall temperatures may also have been responsible for damage observed. Temperature data for the months ofSeptember to November do indicate wide variations. Period maximum/minimum temperatures for the fall of 1998,1999 and 2000 ranged respectively from 35.6 to $-4.4{ }^{\circ} \mathrm{C}\left(96.08\right.$ to $\left.24.08^{\circ} \mathrm{F}\right), 35.6$ to $-8.9^{\circ} \mathrm{C}\left(96.08\right.$ to $\left.15.98^{\circ} \mathrm{F}\right)$, and 34.4 to $-10^{\circ} \mathrm{C}\left(93.92\right.$ to $\left.14.0^{\circ} \mathrm{F}\right)$. This period also included 8,8 and 12 -d of subfreezing $\left[<0^{\circ} \mathrm{C}\left(32.0^{\circ} \mathrm{F}\right)\right]$ minimum temperatures for the respective years.

Due to great variability, significant differences among varieties for the number of flower buds/tree was not observed (Table 3). Seedling trees developed no buds at all and remained in a juvenile stage. Most flower buds did not develop fully to anthesis but instead aborted on the tree. This could have been due to cold damage during the winter 2000-01, or other unknown physiological reasons. The percentage of flower buds that developed into open, viable flowers in Spring 2001 were significantly greater in 'Wells' than all other named varieties except 'Rebeccas Gold'. Interestingly, 'Overleese' had the highest average number of buds per tree (5.6), but only $0.7 \%$ developed into flowers, where as 'Wells' with a moderate number of buds (3.6), had a very high percentage of opened flowers $(63.8 \%)$. No fruit set in any variety with open flowers. This is not surprising because pawpaws have been shown to be strongly protogynous, self-incompatible and require cross pollination by native insects, either fly or beetle species, which may or may not have been present on this site (Willson and Schemske, 1980).
There were no differences in survival but significant differences in growth and development among the seven grafted varieties and the nongrafted seedling strain planted in this trial. The non-grafted seedlings consistently out-paced the grafted varieties in growth parameters such as height and TCSA, but it did not initiate flower buds and instead remained juvenile in character in the time frame evaluated. Second year bud break and subsequent early limb development characteristics were similar for all varieties. Tree height and shoot growth characteristics differed, but differences varied from year to year. Trends for growth patterns did become evident during the three seasons the trees were evaluated, but they were not always significant. Among named varieties, 'Taylor', 'Davis', 'Overleese' and 'Rebeccas Gold' were least vigorous, where as 'Prolific' and 'Sunflower' were most vigorous. Differences in overall growth could be related to rootstock/scion compatibility or simply greater vigor of these varieties. For all entries, lack of apical dominance was exhibited when buds breaking at the top of tipped stems consistently grew less than buds originating from lower locations. This resulted in an early canopy structure resembling a candleabra. These observations may provide insight into early pruning responses as management techniques for this crop are developed. Precocity varied among all varieties in the spring of the fourth year. Not all flower buds developed into an open flower. The percentage of buds opening did not correlate well with initial bud number. Successful early anthesis thus appears to be a variety trait.

Shoot hardiness may be strongly related to ability of the tree to accli- 
mate and harden in the fall before cold temperatures ensue, as indicated by loss of shoot tips to cold damage after the first and third winter. Enhancement of growth by use of grow tubes should be managed closely. The tubes should be removed sometime late in the first growing season, and not allowed to remain on through the winter as occurred in this study. Though rates of $\mathrm{N}$ used in this study would not normally be considered excessive, it is likely rates, timing and possibly source of $\mathrm{N}$ may play a role in winter hardiness.

Early management requirements for success with pawpaw appear to be minimal if good site preparation and care are provided the trees in early years. As for sustainability, no insecticides or fungicides were used to grow the trees in this study, and mulching kept weed competition to a minimum. Because no current herbicide is registered for the crop, mulch is an advantage, though as an observation, trees seemed slower in breaking dormancy with mulch use, and $\mathrm{N}$ applications should be adjusted to compensate for chip breakdown. This site harbored large populations of rodents (meadow voles) under the mulch, however no damage was noted in the planting, indicating a lack of preference for pawpaw wood tissue. However, rodent populations should be monitored when mulch is used. On this site deer pressure was also heavy, but only minor feeding activity was observed on trees in this study.

In summary, variety and seedling survival rates were high under these particular cultural conditions, though there was evidence of cold damage to shoots if inadequately hardened in the fall. Differences in growth were observed between grafted varieties on a genetically similar rootstock, and between grafted and seedling trees. Grafted varieties developed flower buds by the spring of the fourth season, however the percent of flowers developing from buds was variety dependent, and no fruit was set from them. Seedling trees remained juvenile and did not develop flower buds.

\section{Literature cited}

Bailey, L.H. 1960. The standard cyclopedia of horticulture. vol. 1. MacMillan, New York.

Callaway, M.B. 1992. Current research for the commercial development of pawpaw [Asiminatriloba (L.) Dunal.]. HortScience 27:90, 191

Callaway, M.B. 1993. Pawpaw (Asimina triloba), a "tropical" fruit for temperate climates, p. 505-515. In: J. Janick and J. Simon (eds.). New crops: Exploration, research, commercialization. Timber Press, Portland, Ore.

Darrow, G.M. 1975. Minor temperate fruits, p. 276-277. In: J. Janick and J.N. Moore (eds.). Advances in fruit breeding. Purdue Univ. Press, West Lafayette, Ind.

Kral, R. 1960. A revision of Asimina and Deeringothamnus(Annonaceae). Britonnia $12: 233-278$

Layne, D.R. 1996. The pawpaw [Asimina triloba (L.) Dunal.]: A new fruit crop for Kentucky and the United States. HortScience 31:777-784.

Little, T.M. and F.J. Hills. 1978. Agricultural experimentation. Wiley, New York.

Peterson, R.N. 1991. Pawpaw (Asimina),p. 567-600. In: J.N. Moore and J.R. Balling ton (eds.). Genetic resources of temperate fruit and nut crops. Intl. Soc. Hort. Sci., Wageningen, The Netherlands.

Pomper, K.W., D.R. Layne, and R.N. Peterson. 1999. The pawpaw regional variety trial, p. 353-357. In J. Janick (ed.). Perspectives on new crops and new uses. ASHS Press, Alex., Va.

Pomper, K.W., D.R. Layne, and S.C. Jones. 2002a. Incident irradiance and cupric hydroxide container treatment effects on early growth and development of container-grown pawpaw seedlings. J.Amer. Soc. Hort. Sci. 127:13-19.

Pomper, K.W., D.R. Layne, S.C. Jones, and M.G. Kwantes. 2002b. Growth enhancement of container-grown pawpaw seedlings as influenced by media type, root-zone temperature, and fertilization regime. HortScience 37:329-333.

Pomper, K.W., D.R. Layne, and E.B. Reed. $2002 \mathrm{c}$. Determination of the optimal rate of slow-release fertilizer for enhanced growth of pawpaw seedlings in containers. HortTechnology 13:397-401.

Sargent, C.S. 1890. Asimina triloba, p. 2327. In: Silva of North America. Houghton Mifflin, New York.

Willson, M.F. and D.W. Schemske.1980 Pollinator limitation, fruit production, and floral display in pawpaw (Asimina triloba). Bul. Torr. Bot. Club 107:401-408. 